\title{
Gender and Sexuality in the Federal Medical Schools in Brazil: an Analysis of the Curricular Pedagogical Projects
}

\section{Gênero e Sexualidade nas Escolas Médicas Federais do Brasil: uma Análise de Projetos Pedagógicos Curriculares}

\author{
Gustavo Antonio Raimondi $i^{1}$ \\ Yahn Rezende de Abreu ${ }^{\mathrm{I}}$ (iD \\ Isadora Meirelles Borges ${ }^{1}(\mathbb{D}$ \\ Gabriel Benjamin Macedo da Silva ${ }^{1}$ (iD \\ Wallisen Tadashi Hattori ${ }^{1}$ (D) \\ Danilo Borges Paulino ${ }^{\mathrm{I}}$ (D)
}

\section{KEYWORDS}

- Medical Education.

- Gender Identity.

- Sexuality.

- Curriculum.
Introduction: The Brazilian National Curriculum Guidelines (NCG) for undergraduate courses in Medicine since 2014 have highlighted the need to include gender and sexuality in the medical school curricula, aiming at better care for people. Method: Thus, the objective is to identify and analyze the approach of gender and sexuality in the Curriculum Pedagogical Projects (CPP) of the medical courses of the Federal Institutions of Brazil. This is a cross-sectional study of descriptive and documentary analysis, carried out through the analysis of CPP, of the undergraduate medical courses of the Federal Universities of Brazil. Data were obtained from the website of the undergraduate medical course of each higher education institution. In addition, emails were sent to the coordinators of these courses to obtain the updated CPPs. For the quantitative analysis, an initial description of the sample was performed followed by a statistical analysis using the chi-square test to assess whether or not there was an association between the presence of gender and / or sexuality debate in CPP, with the publication of the 2014 NCG and with the Brazilian geographic region, as well as between the nature of the curricular unit (compulsory or complementary / optional) and the perspective of the approach. The documentary analysis was used for the qualitative analysis with the content analysis technique, through the thematic analysis method. Results: It was found that 48 (69.56\%) of the 69 analyzed CPP discuss the topics gender and / or sexuality in one or more subjects offered by the course. There is a predominance of the sexuality topic, of compulsory curricular units (88.32\% of 137 curricular units) and an approach beyond the exclusively biological perspective (63.5\% of 48 CPPs and $62.04 \%$ of curricular units). No statistical significance was evidenced by the chi-square test. Regarding the documentary analysis, two categories were constructed: "gender and sexuality associated with a biological perspective", "gender and sexuality associated with a predominantly broader perspective or social determinants in health". It was observed that the first category predominates in curricular units associated with organs, systems or life cycles of the human being, while the second, to social and human sciences applied to health and Primary Health Care. Conclusions: We conclude there is a significant number of CPPs and, consequently, also of curricular units that have a perspective beyond the exclusively biological approach. Nevertheless, there is difficulty with comprehensive health care that may be related to a selective visibility to pathology and technical aspects of medical practice and a difficulty in effectively promoting an interdisciplinary dialogue between the biological, exact and human sciences as proposed by the NCG. 


\section{PALAVRAS-CHAVE}

- Educação Médica.

- Identidade de Gênero.

- Sexualidade.

- Currículo.

\section{RESUMO}

Introdução: Desde 2014, as Diretrizes Curriculares Nacionais (DCN) para os cursos de graduação em Medicina do Brasil destacam a necessidade da inclusão dos temas gênero e sexualidade nos currículos dos cursos de Medicina, almejando um melhor cuidado com as pessoas. Objetiva-se, com isso, identificar e analisar a abordagem de gênero e sexualidade nos Projetos Pedagógicos Curriculares (PPC) dos cursos de Medicina das Instituições Federais do Brasil. Método: Trata-se de um estudo transversal do tipo descritivo $e$ de análise documental, realizado por meio da análise de PPC dos cursos de graduação em Medicina das Universidades Federais do Brasil. Os dados foram obtidos no sítio eletrônico do curso de graduação de Medicina de cada Instituição de Ensino Superior. Além disso, foram enviadas mensagens por correio eletrônico para as coordenações desses cursos de modo a obter os PPC atualizados. Para a análise quantitativa, realizou-se uma descrição inicial da amostra seguida de uma análise estatística utilizando o teste qui-quadrado para avaliar se haveria associação ou não entre a presença do debate de gênero e/ou sexualidade nos PCC, a publicação das DCN de 2014 e a região geográfica brasileira, bem como entre a natureza da unidade curricular (obrigatória ou complementar/optativa) e a perspectiva da abordagem. Para a análise qualitativa, foi utilizada a análise documental com a técnica de análise de conteúdo por meio do método de análise temática. Resultados: Identificou-se que 48 (69,56\%) dos 69 PPC analisados discutem os temas gênero e/ou sexualidade em uma ou mais disciplinas oferecidas pelo curso. Há um predomínio da temática da sexualidade, de unidades curriculares de caráter obrigatório (88,32\% das 137 unidades curriculares) e de uma abordagem para além da perspectiva exclusivamente biológica (63,5\% dos 48 PPC e 62,04\% das unidades curriculares). Não foram evidenciadas significâncias estatísticas pelo teste qui-quadrado. Em relação à análise documental, construíram-se duas categorias: "gênero e sexualidade associados a uma perspectiva biológica" e "gênero e sexualidade associados a uma perspectiva predominantemente ampliada ou dos determinantes sociais em saúde". Observou-se que a primeira categoria predomina em unidades curriculares associada a órgãos, sistemas ou ciclos de vida do ser humano, enquanto a segunda, às Ciências Sociais e Humanas aplicadas à Saúde e à Atenção Primária à Saúde. Conclusões: Há uma quantidade relevante de PPC e, consequentemente, de unidades curriculares que têm uma perspectiva para além da abordagem exclusivamente biológica. Apesar disso, há uma dificuldade para um cuidado integral em saúde que pode estar relacionado a uma visibilidade seletiva à patologia e aos aspectos técnicos da prática médica e a uma dificuldade de efetivamente promover um diálogo interdisciplinar entre as ciências biológicas, exatas e humanas como proposto pelas DCN.

Received on $9 / 6 / 19$

Accepted on 10/8/19

\section{INTRODUCTION}

In most societies, gender relations are unequal, and these inequalities are evident in laws, policies and social practices, in people's identities, attitudes and behaviors. These imbalances tend to deepen other social inequalities and discrimination, such as those of class, race, age, sexual orientation, ethnicity, disability, language and/or religion, among others ${ }^{1}$.

In the $60 \mathrm{~s}$ and $70 \mathrm{~s}$, with the increasing visibility of the feminist movement, women also began to demand a change in health paradigms, in which their bodies were seen only as reproducers of the species and government programs focused on the health of women in the context of the pregnancy-puerperal period ${ }^{2}$. In 1984, the Comprehensive Assistance Program for Women's Health (PAISM, Programa de Assistência Integral à Saúde da Mulher), in Brazil, appears to break with this restrictive concept, expanding the vision of women's health needs ${ }^{2}$.

Continuing the achievements for comprehensive, equitable and universal health care, the Citizen Constitution of 1988 states that health, seen in a broader way, is considered a right of all citizens and a duty of the Government, establishing the legal framework for the advent of the Brazilian Unified Health System (SUS, Sistema Único de Saúde), expanding the view of health care ${ }^{3,4}$. In 2004, the National Policy for Integral
Attention to Women's Health was published, which incorporates gender as a guideline for comprehensive health care for women, considering this concept as a determinant in health ${ }^{1}$.

In addition to the discussion of gender in the context of "women's health", it should also be noted that, historically, the population of Lesbians, Gays, Bisexuals, Transvestites and Transsexuals (LGBT) faces barriers to have access to health services and to the quality of services offered to them, both nationally ${ }^{5-8}$ and internationally ${ }^{9-11}$. These barriers reflect those faced by the population in society, that is, discrimination based on sexual orientation and gender identity and the social stigma faced by this population that affect the social determination of the healthdisease process ${ }^{5,10}$.

These inequalities and barriers bring to LGBT people specific health needs, such as addressing gender identity issues, sexually transmitted disease prevention guidelines for men who have sex with other men and women who have sex with other women, hormone therapy and sexual reassignment surgery for transsexual individuals, among others, which require health professionals to understand the subject ${ }^{5,12}$. In 2007, with the report of the $13^{\text {th }}$ National Health Conference, the topic starts to be included as an organizing element of Public Policies. Four years later,

REVISTA BRASILEIRA DE EDUCAÇÃO MÉDICA

2 44 (2) : e045; 2020 
the National Policy for Comprehensive Health Care for Lesbians, Gays, Bisexuals, Transvestites and Transsexuals is published, of which intention is to reduce inequalities due to sexual orientation and gender identification and, above all, related to the health of these social groups ${ }^{5}$.

In this line of discussions, the World Health Organization (WHO) points out that a key element for the promotion of gender equality policies in health and the promotion of human rights in teaching and health practices is to address these issues in an integral and transversal way in undergraduate curricula for health professionals ${ }^{13}$. In agreement with the WHO, in Brazil, the National Education Council established in 2012 the National Guidelines for Education in Human Rights that reiterate the "recognition and appreciation of difference and diversity" (p. 48) $)^{14}$ as the basis for the promotion of education and social transformation. Additionally, the National Curricular Guidelines (NCG) for undergraduate medical courses reiterate the expansion of health care that considers human rights, as well as corroborating the perspective of health care based on social determinants of health $(\mathrm{SDH})^{15}$.

In Brazil, it can be observed that from the teaching perspective, the topic of sexuality is predominantly addressed in a non-standardized and fragmented way, with a predominance of topics with an organic/ biological and pathological bias ${ }^{16}$. However, there is no information, regarding medical courses in Brazil, on the integration of the topics of gender and sexuality with Curricular Pedagogical Projects (CPP), which constitute the official institutional documents about the contents to be addressed and the planning of the approach to these contents throughout undergraduate school ${ }^{15}$. Therefore, this study aims to identify and analyze, through a qualitative and quantitative analysis, the presence or absence of contents that address the topics of gender and sexuality in the CPPs of Medicine courses at Federal Institutions in Brazil.

\section{MATERIAL AND METHODS}

Study type

This is a cross-sectional study of the descriptive type and document analysis with the construction of thematic categories, carried out through the analysis of CPPs of medical courses at federal public universities.

Sample

For the authors' convenience, the $78 \mathrm{CPPs}$ of undergraduate courses in Medicine from 54 Federal Public Universities were considered.

\section{Procedures}

This study was based on the document analysis research design used by Silva, Paulino \& Raimondi ${ }^{17}$, when analyzing the gender and sexuality approach in the CPPs of undergraduate courses in Public Health in public higher education institutions in Brazil. In addition, this study design was expanded to include a quantitative analysis of the data.

Thus, the present research analyzed the CPP of each assessed educational institution listed in the Ministry of Education website, between January and April 2019 (year of data collection). The CPPs were obtained through the website of the respective Universities. Moreover, messages were sent by e-mail to the medical course coordinators of all Federal Public Universities, in order to obtain updated CPPs. Institutions that did not return messages via e-mail after three attempts, had the electronically available CPP analyzed. In the case of institutions that did not make the CPP available on their website, it was requested to be sent via e-mail, available on those same websites. CPPs that were not sent after the third attempt to obtain them via e-mail were disregarded.

After the CPPs were collected, the documents were read to identify the descriptors "gender identity" and/or "sexuality". The choice of these search descriptors was made after consulting the Health Sciences Descriptors of the PAHO Regional Medical Library, using non-controlled, free language based on the concepts of the respective descriptors to expand the search. Subsequently, quantitative and qualitative analysis methods were applied.

\section{Data analysis}

For the quantitative analysis, the following variables were considered: presence of the approach of the gender and/or sexuality topic based on the identification of the descriptors "gender identity" and "sexuality" (yes or no) and number of curricular units that address the topics; year of the CPP publication (before 2014 or after 2014); Brazilian geographic region of the Institution; nature of the curricular unit (mandatory or complementary/ optional); perspective of the curricular unit's approach - biological or SDH (approaches that consider social, economic, cultural, ethnic/racial, gender identity, affective-sexual orientation, psychological and behavioral factors in the health-disease-care process) or extended (approaches that consider a perspective beyond biology but without an explicit articulation with the SDH perspective).

Subsequently, a quantitative descriptive analysis of the sample was carried out, based on these variables, followed by a statistical analysis using the chi-square test to assess whether or not there would be an association between the presence of the gender and/ or sexuality debate in the CPPs with the publication of the 2014 NCG and with the Brazilian geographic region, as well as between the nature of the course and the approach perspective.

For the qualitative analysis, document analysis was used with the content analysis technique through the thematic analysis method proposed by Minayo $^{18}$ : pre-analysis, evaluation of the material, treatment of the obtained results and interpretation. Thus, the material can be initially discriminated and then interpreted in a critical-reflexive way. Considering this method, the first step was to read all the projects and identify in them which ones contained the words "gender identity" and/or "sexuality" and which ones did not. Then, in the projects that contemplated these expressions, we sought to identify how the approach to these issues was predicted. Hence, two categories of thematic analysis were constructed within the content analysis of the material: gender and sexuality associated with a predominantly biological perspective; gender and sexuality associated with a predominantly extended perspective or the SDH.

\section{Ethical aspects}

It is noteworthy that the CPPs are considered as public domain documents according to the Ministry of Education (MEC) Normative Ordinance N. 40 of December 12, 2007 ${ }^{19}$. Therefore, there was no need to submit this research to the Research Ethics Committee, according to Resolution N. 510, of April 7, 2016 of the National Health Council ${ }^{20}$. Even so, we chose a randomized encoding method using four Arabic digits in relation to the CPP names of each institution, in order to minimize possible risks of document identification related to a specific institution.

REVISTA BRASILEIRA DE EDUCAÇ̄̃o MÉDICA

3 44 (2) : e045; 2020 


\section{RESULTS}

A total of $78 \mathrm{CPPs}$ of undergraduate medical courses from 54 Federal Higher Education Institutions (FHEI) were identified on the virtual platform of the Ministry of Education (MEC), the e-Mec. Of these, 69 had their CPP included in the analysis of this study, of which 16 were obtained from responses to e-mails sent to the coordinators of the institutions' medical courses being assessed and 53 were obtained from the institutions' websites. The others were excluded because they did not display the CPPs on the institution's website and did not answer the 3 e-mail attempts sent to them.

Considering these 69 PPCs, 10 are from the North region (which has 10 FHEI Medicine courses), 21 are from the Northeast region (which has 25 FHEI Medicine courses), 7 are from the Midwest region (which has 9 FHEI Medicine courses), 19 are from the Southeast region (which has 21 FHEI Medicine courses) and 12 are from the South region (which has 13 FHEI Medicine courses).

The 69 CPPs included in the analysis were read in full, aiming to identify the research keywords. In 48 CPPs $(69.56 \%)$ at least one of the keywords was identified (Figure 1). Regarding the geographical region, 7 (14.58\%) are from the North region (of the 10 FHEI Medicine courses included in the analysis), $16(33.34 \%)$ are from the Northeast region (of the 21 FHEI Medicine courses included in the analysis), 5 (10.42\%) are from the Midwest region (of the 7 FHEI Medicine courses included in the analysis), $11(22.92 \%)$ are from the Southeast region (of the 19 FHEI Medicine courses included in the analysis) and 9 (18.75\%) are from the South region (of the 12 FHEI Medicine courses included in the analysis) (Figure 2). Regarding the topic, there is a predominance of the sexuality topic in the CPPs of all geographical regions (Figure 02), with an approach beyond the exclusively biological perspective $(63.5 \%$ of the $48 \mathrm{CPPs}$ ) (Figure 3).

Moreover, among the 48 documents that included the keywords, 16 CPPs (33.34\%) were published before the NCG, which encourage the discussion of these topics in the curriculum of medical courses; and 32 CPPs (66.67\%) were published after the NCG. Among the 21 CPPs that do not address any of the topics, $11(52.38 \%)$ were published before the NCG, 9 (42.86\%) were published after the NCG and in $1(4.76 \%)$ it was not possible to identify the publication date.

The analysis of these 48 CPPs also showed the presence, in all of them, of 137 curricular units in which the terms gender / gender identity and / or sexuality are mentioned in their syllabi, with the number of curricular units varying from 1 to 26 in each CPP, a mean of 2.85 curricular units per CPP, median of 2 units per CPP and mode of 1 curricular unit per CPP. It is noteworthy that a CPP had 26 curricular units that contained both words, as it described in the syllabus the need for an "ethical and professional attitude" that considers "gender and sexual orientation diversity".

Regarding the NCG, 31 (22.63\%) of these courses are in CPPs published before the NCG and 106 (77.37\%) are in CPPs published after the NCG; 36 (75\%) of the curricular units that have a biological approach

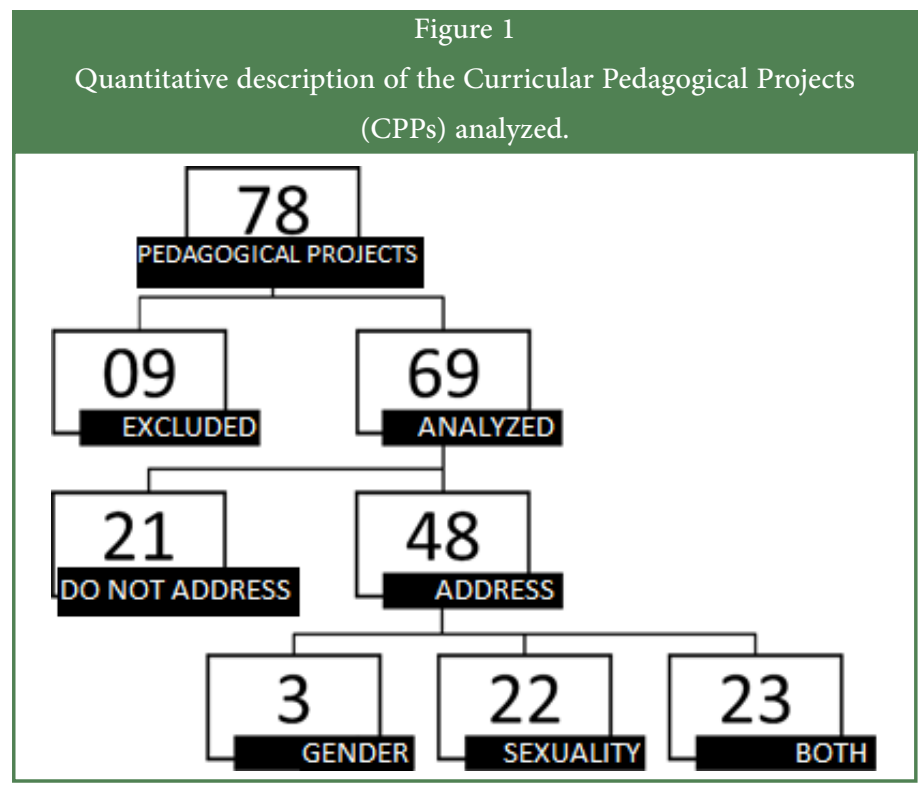

Source: The authors.

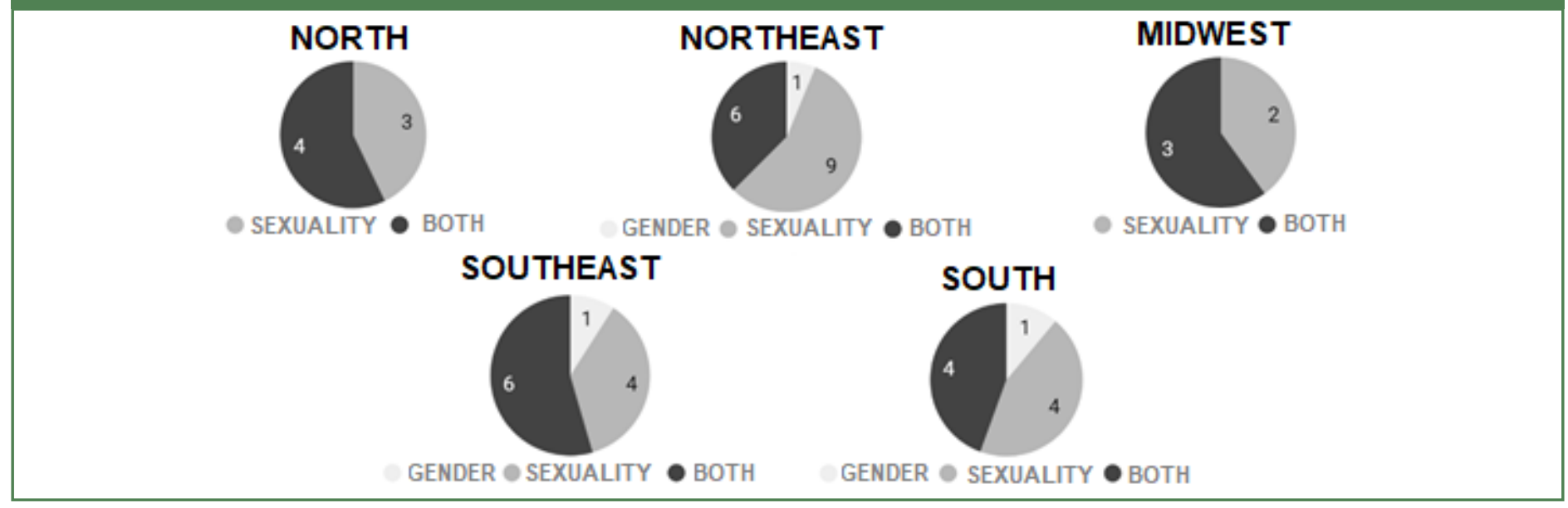

Source: The authors. 
date from after the NCG, which occurs with $20(74 \%)$ of those that have an SDH approach and $46(79.31 \%)$ of those that have a broader approach. All those curricular units in which it was not possible to identify the approach, date from after the NCG.

Regarding the nature of the curricular units, 121 (88.32\%) are mandatory, of which 46 have a biological approach, 23 have an SDH-related approach, 50 have an extended approach and in two the approach was not identified. Of the $15(10.95 \%)$ curricular units that are complementary / optional, 1 has a biological approach, 4 have an SDH-related approach, 8 have an extended approach and in 2 it was not possible to identify the approach. Additionally, there is $1(0.73 \%)$ curricular unit that has no information regarding its nature and has a biological approach. Thus, it can be observed that $62.04 \%$ of the curricular units have an approach that goes beyond the biological one (Figure 04 ).

There were no significant associations, through the chi-square test, between the approach or not of the topics with the geographic region or

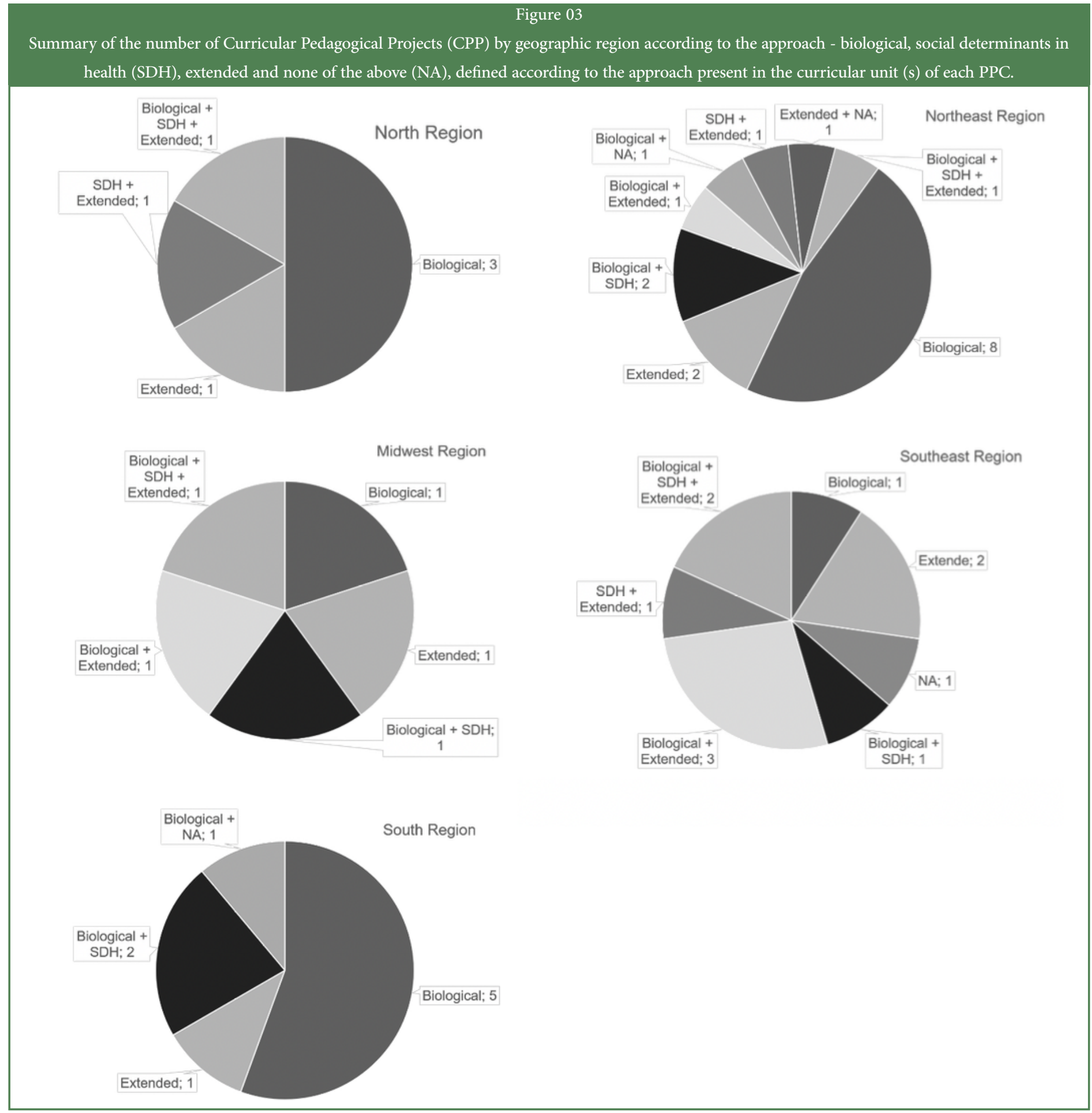

Source: The authors.

$5 \mid$\begin{tabular}{l|l} 
REVISTA BRASILEIRA DE EDUCAÇÃO MÉDICA \\
44 (2) : e045; 2020
\end{tabular} 
the date of publication of the CPP or between the nature of the curricular unit (mandatory or complementary / optional) and the approach perspective (biological, SDH or extended).

Regarding the documentary analysis through the content analysis technique using the thematic analysis method, in the category "gender and sexuality associated with a biological perspective", all curricular units of the analyzed CPPs that dealt with gender and sexuality, in which the predominant perspective of the syllabus was related to biology were included. It can be observed, from the first moment, that this category is characterized by the priority focus that the CPPs give on sexuality to the detriment of gender and other SDH issues. In this sense, gender and, especially sexuality, are approached as components of the universe of the biological aspect, of nature, closely related to the physiological and pathological functions of the human body, being linked to six main topics: sexual development in adolescents; the processes related to / pregnancy / childbirth / puerperal period; sexually transmitted infections; aging; psychiatry; and male sexual dysfunction. It is possible to observe a predominance of the first three topics, with greater emphasis on the frequency of the second element:

Development of secondary somatic and sexual characters. (CPP 8950).

Growth and puberty. Normal adolescent syndrome. Sexuality, pregnancy and contraception in adolescence. The adolescent at risk situations. (CPP 9642).

Sexuality in adult women and adolescents. Prevention of sexually transmitted diseases. (CPP 6813).
Reproductive problems and irregularities during pregnancy and childbirth and problems related to human sexuality; contraception. (CPP 1162).

Care of the elderly with chronic pathologies. The elderly and sexuality. (CPP 9282)

Male sexual dysfunction. Sexually transmitted infections. (CPP 2753).

In this category, there are syllabi that also deal with sexuality based on the standardization strictly related to the biology of "normal" or "expected" sexual development, conceiving its variations as pathological, as in the examples below:

Information and knowledge evaluation [...] referring to the anatomy of the female reproductive system in the different phases, identification of its deviations and preventive guidance with treatment of the most prevalent gynecological and obstetric pathologies. (CPP 2269).

Describe the aspects of normal sexuality and its inadequacies. (CPP 6320).

In the category "gender and sexuality associated with a predominantly extended perspective or with social determinants of health", the approach to sexuality and gender issues is characterized mainly by the debate about the SDH. There is a more evident explanation of the term gender in connection to other SDH as "race-ethnicity". Thus, this debate arises when there is no reiteration of a pedagogical proposal connected only to

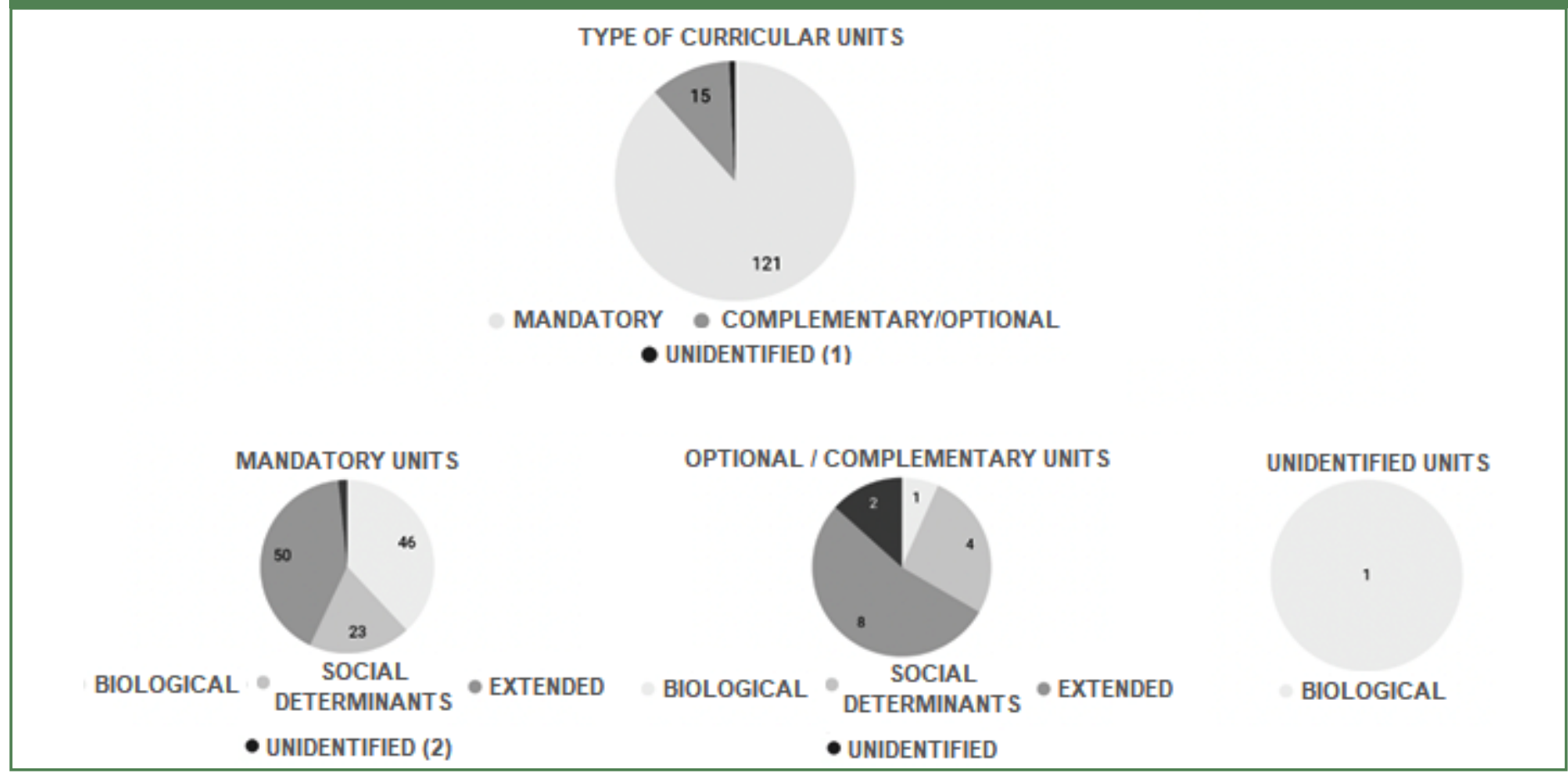

Source: The authors.

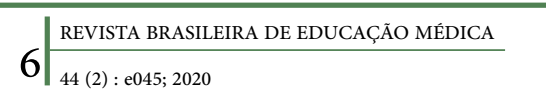


age groups or life cycles or to medical specialties that follow an anatomical discrimination for example, but rather to a perspective of the subject's integrality, as demonstrated in some CPPs that make a bioethical, social, historical, sociological, anthropological and cultural analysis of these determinants in the health-disease-care process. There is even a debate about power relations and human rights, according to the examples:

Health disparities and inequalities; Social determination of the health-disease process; Epidemiology and inequalities. The woman and her history. Sociocultural and biological aspects. Class exploitation and gender oppression. Gender: concept and gender relations. Gender identity and sexual identity. Gender equality and gender equity. The sciences and discrimination against women. Medicine and the expropriation of the woman's body. The medicalization of the woman's body. Sexuality. Reproductive rights and sexual rights. Abortion and the secular state controversy. The controversy between women's health and maternal and child health. Women's health in the SUS, principles and programs. The epidemiology of violence against women. Women's rights as human rights. (CPP 9386).

Historical perspective of gender inequalities. [...] Typification of violence against women. The Maria da Penha Law and advances against violence in Brazil. Future perspectives of the feminist movement and the struggle for gender equality. Gender implications in the process of disease and in the Health System organization. (CPP 1234).

Identity, gender, religiosity and ethnic-racial relations. (PPC 5906).

It is important to note that in this category, there is an expansion of the debate around gender and sexuality for different health-disease-care scenarios, different population groups and for issues related to prejudice, violence, racism, sexism, machismo and LGBTphobia, according to the examples :

\section{[...] the sexuality of the doctor and of the patient. (CPP 7544).}

Gender differences and diversity in the classroom. (CPP 5906).

Gender-based violence in different settings: domestic, sexual and obstetric. [...]. Comprehensive health care for women in indigenous, black, quilombola, gay, bisexual, transvestite, transsexual, transgender populations, rural workers, women with disabilities, at risk, inmate situations. (CPP 2929).

Gender Violence and LGBTphobia. (CPP 2929).

It is noteworthy that in the category "gender and sexuality associated with a biological perspective", curricular units related to human organs, systems or life cycles predominate. In contrast, in the category "gender and sexuality associated with a perspective of social determinants in health", curricular units related to social and human sciences applied to health and Primary Health Care predominate.

\section{DISCUSSION}

The presence of the debate on the topics of gender and / or sexuality in more than $50 \%$ of the CPPs is in line with international ${ }^{21-25}$ and national ${ }^{5,15}$ guidelines on the subject. Accessing these elements, as proposed by these CPPs, expands comprehensive health care practices. It is necessary to integrate care, territory, family, work, society, human rights, SDH, among many other elements that are important, associating them to the signs and symptoms presented by the individuals.

This change disrupts the biomedical precepts ${ }^{26}$ and expands the concept of the biopsychosocial being and may also concur with the understanding of social determination in the health-disease-care process ${ }^{27}$. From this perspective, gender is included as a useful category of analysis ${ }^{28}$ and problematization of health care, as a possible strategy to reduce the harmful effects of health inequities ${ }^{29}$. This reiterates the perspective of Contatore, Malfitano \& Barros $^{26}$ that care based only on technicalscientific aspects does not meet the needs of comprehensive health care, which requires an emancipatory "social + logical" approach.

Moreover, the articulation of different social markers of difference can enhance the critical reflection on the ways through which power devices are activated in health care practices ${ }^{30}$. In this wake of discussion, Sharma, Pinto \& Kumagai $^{31}$ reiterate that, to enhance the achievement of equity in health, the official course documents are necessary, such as CPPs, to focus on SDH as "conditions to be challenged" and not only as "facts to be known". In other words, it is essential, for instance, to have a debate on violence against women, sexism, racism, LGBTphobia together with the social markers of difference ${ }^{31}$ in the health-disease-care process and in the organization of health care. This is observed in some analyzed curricular units, which are present in the category "gender and sexuality associated with a predominantly extended perspective or the social determinants in health".

Additionally, one can observe the presence of issues that have not been debated until this time, such as sexuality of the elderly population, which in many situations is included within a culture of asexuality and in which sexuality would be an experience directed only at the younger population $^{32}$. Thus, this training can reduce professional behaviors of "being ashamed", "being impatient", "pretending not to have heard", "not knowing what to do" and / or "joking to lighten the mood"33, which results in an improvement of skills related to comprehensive health care ${ }^{34,35}$.

These CPPs and course units that provide these approaches are located mainly in the northeast region. It is important to consider the strong performance of the social movements involved with these topics in this region, such as, for example, with the Gay Group of Bahia, in the state of Bahia. This is considered one of the first civilian groups in Brazil to defend LGBT rights, providing an extension of the debate around gender and sexuality issues, including in health care and training ${ }^{5}$. Nevertheless, there is a need for other research methodologies to assess a possible association between a higher number of CPPs and curricular units and these social movements.

Despite these issues, it can be observed in the CPPs, as well as in the curricular units, that there is still a gap in the expansion of clinical skills that go beyond the body of heterosexual individuals. This is also observed by Bonvicini ${ }^{11}$ when seeking to understand the changes in American medical education after 15 years of publications on the expansion of the topic of gender and sexuality beyond heterosexuality.

In addition, one can identify a predominance of the topic around sexuality, to the detriment of gender, as observed from the students ${ }^{36}$ and teachers ${ }^{36}$ perspectives in Brazil and other countries ${ }^{11,12,37-39}$. It is

REVISTA BRASILEIRA DE EDUCAÇ̄̃̃ MÉDICA

7 74 (2) : e045; 2020 
noteworthy that, even after the publication of the NCG for Undergraduate Medical courses ${ }^{15}$, in which the need to address both topics is explained, there is a greater number of CPPs and, consequently, of curricular units that work on the topic of sexuality, even without identifying a statistical association between NCGs and CPPs.

In this sense, a close association between sexuality and the physical body is also identified, between sexuality and the diseases that can be acquired by expressing it, experiencing it; and leaving in the background or neglecting the approach of gender, and other expressions, of other performances of sexuality that go beyond the body. There is a reiteration of the body as a universal and unquestionable fact, of the "nature" inherent to body processes ${ }^{40}$. This may be one of the elements that results in the perpetuation of the heteronormative matrix in medical training ${ }^{41}$. In this sense, it is reiterated that a supposed fixed identity of the subjects lies in their genitalia, since a certain genitalia indicates a certain gender that, in turn, induces a certain affective-sexual orientation ${ }^{42,43}$.

However, it must be considered that there is a quantitative predominance of curricular units and, consequently, of CPPs that have an approach that goes beyond the exclusively biological perspective, which occurs mainly in the CPPs published after the NCG for undergraduate courses in Medicine. Nonetheless, what is reflected in health care practices is a "selective visibility" for care directed at genitals, to reproduction / childbirth / puerperal period and STIs / HIV / AIDS. This is evidenced, for instance, by authors who investigated the care practices aimed at the LGBT population ${ }^{8,39,41,44}$. Thus, portraying the hegemonic predominance and a greater appreciation of a health care and teaching practice focused on "nature" ${ }^{41,45}$, disregarding the subjectivity immersed in the social and cultural processes and with an emancipatory "social + logical" perspective ${ }^{26}$.

Moreover, we have to consider that the analyzed CPPs and the curricular units tend to be succinct and may not have updates that occurred in certain curricular units, without necessarily having issued an updated version of the CPP. Furthermore, as it is a neglected topic, it is possible that the descriptors used here for analysis did not appear during the reading of the CPPs and / or that other terms may have been chosen by each educational institution to refer to gender and / or sexuality issues. Moreover, to enhance this discussion, new studies involving the analysis of the CPPs of all undergraduate courses in Medicine in Brazil, since the present study analyzed only the federal courses, as well as the analysis of the "live" curriculum, present in the actual daily training of future doctors, making an intersection with other SDH, are essential to understand this issue in the national scenario.

Seeking to overcoming the binary notion "we-and-them", "biologyand-social / cultural", can also effectively promote an interdisciplinary dialogue between the biological, exact and human sciences ${ }^{46}$, in order to guarantee integral, humanistic and socially endorsed training ${ }^{15}$, in which a pedagogy of hope ${ }^{47}$ is possible and promulgated, as reiterated by Paulino et al. ${ }^{8}$, Rufino et al. ${ }^{16}$ and Raimondi et al. ${ }^{35}$. Thus, the conception of biologicist "reductionisms" of medical education is expanded ${ }^{46}$, providing the development of reflections on health and disease as existential and societal, individual and collective phenomena ${ }^{48}$.

\section{CONCLUSIONS}

Considering this analysis, it becomes evident that we should not fall into the essentialism of separating biological from social, aiming that one discussion may supplant the other. The present analysis demonstrates a new construction of the CPPs based on the guidelines of the official documents cited herein, in the sense of integrating these approaches, offering training that considers the integrality of the people that receive care.

Therefore, strategies to improve curricular activities should be considered, as described in the CPPs and in the curricular units. By explicitly discriminating the terms used in this research in the CPPs, an important institutional discourse is produced, which may have an effect on teaching-learning practices. Hence, by making the $\mathrm{SDH}$ approach explicit in a transversal way to academic education, including discussions of the harmful effects of health inequities and manifest prejudice, for example, in sexism, machismo and LGBTphobia, makes it possible to expand the perspective of academic education and healthcare, ensuring comprehensive care based on the subjects' autonomy and human rights.

\section{ACKNOWLEDGEMENTS}

We are grateful for the opportunity to carry out this research, within the scope of the Scientific Method curricular components of the Medicine course at the Federal University of Uberlândia (UFU). We also thank the undergraduate student (by the time we conducted this research) at the UFU Medicine course, Leandro Amorim de Faria, for his contributions to the initial construction of this research.

\section{REFERENCES}

1. Brasil. Política nacional de atenção integral à saúde da mulher: princípios e diretrizes. Brasília, DF: Ministério da Saúde; 2004. 80 p. (Série C. Projetos, programas e relatórios).

2. Rohden F. A construção da diferença sexual na medicina. Cad. Saúde Pública 2003;19:S201-12.

3. Brasil. Constituição (1988). Constituição da República Federativa do Brasil. Brasília, DF: Senado Federal; 1988. 292 p.

4. Brasil, Casa Civil. Lei no 8.080, de 19 de setembro de 1990. Dispõe sobre as condições para a promoção, proteção e recuperação da saúde, a organização e o funcionamento dos serviços correspondentes e dá outras providências. Diário Oficial da União 1990; 28(182), p.1.

5. Brasil. Política Nacional de Saúde Integral de Lésbicas, Gays, Bissexuais, Travestis e Transexuais. Brasília, DF: Ministério da Saúde; 2013. 32 p.

6. Moscheta MDS, Fébole DDS, Anzolin B. Visibilidade seletiva: a influência da heterossexualidade compulsória nos cuidados em saúde de homens gays e mulheres lésbicas e bissexuais. Saúde transform. soc. 2016;7(3):71-83.

7. Facchini R, Barbosa RM. Dossiê saúde das mulheres lésbicas: promoção da equidade e da integralidade. Belo Horizonte: Rede Feminista de Saúde; 2006.

8. Paulino DB, Rasera EF, Teixeira FB. Discursos sobre o cuidado em saúde de Lésbicas, Gays, Bissexuais, Travestis, Transexuais (LGBT) entre médicas(os) da Estratégia Saúde da Família. Interface (Botucatu) 2019;23:e180279.

9. Nevilla S, Henrickson M. Perceptions of lesbian, gay and bisexual people of primary healthcare services. J. adv. nurs. 2006; 55(4):407-15.

10. Smith SK, Turell, SC. Perceptions of healthcare experiences: relational and communicative competencies to improve carefor LGBT people. J. soc. issues 2017;73(3):637-57 
11. Bonvicini K. LGBT healthcare disparities: what progress have we made? Patient educ. couns. 2017;100(12):2357-61.

12. Obedin-Maliver J, Goldsmith ES, Stewart L, White W, Tran E, Brenman $\mathrm{S}$, et al. Lesbian, gay, bisexual, and transgender-related content in undergraduate medical education. JAMA 2011;306(9):971-7.

13. World Health Organization, et al. Integrating gender into the curricula for health professionals. Department of Gender. In: Women and Health (GWH). Meeting report. 2006. p. 4-6.

14. Brasil. Resolução ${ }^{\circ} 1$, de 30 de maio de 2012. Estabelece Diretrizes Nacionais para a Educação em Direitos Humanos. Diário Oficial da União, 31 maio 2012; Seção 1, p. 48-50.

15. Brasil. Resolução CNE/CES no 3 , de 20 de junho de 2014. Institui Diretrizes Curriculares Nacionais do Curso de Graduação em Medicina e dá outras providências. Diário Oficial da União 23 jun 2014; Seção 1, p. 8-11.

16. Rufino AC, Madeiro A, Girão MJBC. Sexuality education in Brazilian medical schools. J. sex. med. 2014;11:1110-7.

17. Silva JMN, Paulino DB, Raimondi GA. Gênero e sexualidade na graduação em Saúde Coletiva do Brasil. Ciênc Saúde Colet. [periódico na internet] (2018/Out). [Citado em 24/02/2019]. Acesso em: 24 fev 2019. Disponível em: http://www.cienciaesaudecoletiva.com.br/ artigos/genero-e-sexualidade-na-graduacao-em-saude-coletiva-dobrasil/16967?id=16967.

18. Minayo MC de S. O desafio do conhecimento: pesquisa qualitativa em saúde. São Paulo: Hucitec; 2008.

19. Brasil. Ministério da Educação. Portaria $n^{\circ} 40$, de 12 de dezembro de 2007. Institui o e-MEC, sistema eletrônico de fluxo de trabalho e gerenciamento de informações relativas aos processos de regulação, avaliação e supervisão da educação superior no sistema federal de educação, e o Cadastro e-MEC de Instituições e Cursos Superiores e consolida disposições sobre indicadores de qualidade, banco de avaliadores (Basis) e o Exame Nacional de Desempenho de Estudantes (ENADE) e outras disposições. Diário Oficial da União $29 \mathrm{dez}$ 2007; Seção 1, p. 23.

20. Brasil. Conselho Nacional de Saúde. Resolução no 510 , de 7 de abril de 2016. Dispõe sobre as normas aplicáveis a pesquisas em Ciências Humanas e Sociais cujos procedimentos metodológicos envolvam a utilização de dados diretamente obtidos com os participantes ou de informações identificáveis ou que possam acarretar riscos maiores do que os existentes na vida cotidiana, na forma definida nesta Resolução. Diário Oficial da União 24 maio 2016; Seção 1, p. 44.

21. World Health Organization. Who regional strategy on sexual and reproductive health. Copenhagen: WHO; 2001.

22. World Association for Sexual Health. Sexual health for the millennium: a declaration and technical document. Minneapolis: World Association for Sexual Health; 2008.

23. World Associaciation for Sexual Health. Declaration of sexual rights. Prague: World Associaciation for Sexual Health; 2014. Disponível em: http://www.worldsexology.org/wp-content/uploads/2013/08/declaration_ of_sexual_rights_sep03_2014.pdf. Acesso em: 01 ago 2019.

24. The International Commission of Jurists, The International Service For Human Rights. The Yogyakarta Principles: principles on the application of international human rights law in relation to sexual orientation and gender identity. Yogyakarta: United Nation; 2007. Disponível em: http:// yogyakartaprinciples.org/wp-content/uploads/2016/08/principles_ en.pdf. Acesso em: 01 ago 2019.

25. The International Service for Human Rights, The International Commission of Jurists. The Yogyakarta Principles Plus 10: additional principles and State obligations on the application of International Human Rights Law in relation to sexual orientation, gender identity, gender expression and sex characteristics to complement the Yogyakarta. Geneva: United Nation; 2017.

26. Contatore OA, Malfitano APS, Barros NF. Os cuidados em saúde: ontologia, hermenêutica e teleologia. Interface (Botucatu) 2017;21(62):553-63.

27. Batistella C. Abordagens contemporâneas do conceito de saúde. In: Fonseca AF, Corbo AD, organizadores. O território e o processo saúde-doença. Rio de Janeiro: EPSJV, Fiocruz; 2007. p. 51-86.

28. Scott JW. Gender: a useful category of historical analysis. The American Historical Review 1986;91(5):1053-75.

29. Barata RB. Como e por que as desigualdades sociais fazem mal à saúde. Rio de Janeiro: Fiocruz; 2009.

30. Moutinho L. Diferenças e desigualdades negociadas: raça, sexualidade e gênero em produções acadêmicas recentes. Cadernos Pagu 2014;42(1):201-48.

31. Sharma M, Pinto AD, Kumagai AK. Teaching the social determinants of health: a path to equity or a road to nowhere? Acad. med. 2018;93(1):25-30

32. Alencar DL de, Marques AP de O, Leal MCC, Vieira J de CM. Fatores que interferem na sexualidade de idosos: uma revisão integrativa. Ciênc. Saúde Colet. 2014;19(8):3533-42.

33. Abdo CHN. Estudo da vida sexual do brasileiro (ESVB). São Paulo: Bregantini; 2004.

34. Rufino AC, Madeiro AP. 6 práticas educativas em saúde: integrando sexualidade e gênero na graduação em Medicina. Rev. bras. educ. méd. 2017; 41(1):170-8. Acesso em: 12 jul 2019.

35. Raimondi GA, Paulino DB, Hattori WT, Limirio Junior V, Lima e Silva VMO, Zaidhaft S. Ensino aprendizagem de gênero e sexualidade em um curso de Medicina no Brasil: promovendo o cuidado integral em saúde e os direitos humanos. Rev. bras. educ. méd. 2019;43(2):130-42.

36. Rufino AC, Madeiro AP, Girão, MJBC. O ensino da sexualidade nos cursos médicos: a percepção de estudantes do Piauí. Rev. bras. educ. méd. 2013; 37(2):178-85.

37. White W. LGBT education in medical school: are we being adequately prepared? In: AAMC Anual Meeting; 2012; San Francisco.

38. Eisenberg K, Dahlstrom J, Carnovale A, Neeman T, Ellwood D. Gender awareness in a medical curriculum: surveying final year students undertaking a women's health rotation. Med. teach. 2013;35(11):970-1.

39. Parameshwaran V, Cockbain BC, Hillyard M, Price JR. Is the lack of specific lesbian, gay, bisexual, transgender and queer/questioning (LGBTQ) health care education in medical school a cause for concern? Evidence from a survey of knowledge and practice among UK medical students. J. homosex. 2017;64(3):367-81.

40. Moore $\mathrm{H}$. Understanding sex and gender. In: Ingold $\mathrm{T}$, editor. Companion encyclopedia of anthropology. London: Routledge; 1996. p. 813-30.

REVISTA BRASILEIRA DE EDUCAÇÃO MÉDICA

9 44 (2) : e045; 2020 
41. Raimondi GA, Teixeira FB, Moreira C, Barros NF. Corpos (não) controlados: efeitos dos discursos sobre sexualidades em uma escola médica brasileira. Rev. bras. educ. méd. 2019;43(3):16-26.

42. Butler J. Problemas de gênero: feminismo e subversão da identidade. 11. ed. Rio de Janeiro: Civilização Brasileira; 2016.

43. Louro GL. Um corpo estranho: ensaios sobre sexualidade e teoria queer. 2. ed. Belo Horizonte: Autêntica; 2013.

44. Moscheta MDS. Responsividade como recurso relacional para a qualificação da assistência à saúde de lésbicas, gays, bissexuais, travestis e transexuais. São Paulo; 2011. Doutorado [Tese] Universidade de São Paulo.

45. Monrouxe LV, Rees, CE. Picking up the gauntlet: constructing medical education as a social science. Med. educ. 2009;43(3):196-8.

46. Barros NF de. As ciências sociais na educação médica. São Paulo: Hucitec; 2016.

47. Freire P. Pedagogia da esperança: um reencontro com a pedagogia do oprimido. 21. ed. São Paulo: Paz e Terra; 2014.

48. Canesqui AM. Sobre a presença das ciências sociais e humanas na saúde pública. Saúde Soc. 2011; 20(1):16-21.

\section{AUTHORS CONTRIBUTION}

All authors participated in the project design and preparation; data collection and analysis; and the writing and revision of the manuscript.

\section{CONFLICTS OF INTEREST}

The authors declare no conflicts of interest.

\section{ADDRESSS FOR CORRESPONDENCE}

Gustavo Antonio Raimondi. Universidade Federal de Uberlândia, Faculdade de Medicina, Departamento de Saúde Coletiva, Avenida Pará, 1720, Campus Umuarama, Bloco 2U, Sala 8, Umuarama, Uberlândia, MG, Brasil. CEP: 38405-320.

E-mail: gustavo_raimondi@ufu.br 